\title{
INOVASI PRODUK KRIYA DI BALI
}

\author{
I Wayan Mudra ${ }^{1^{*}}$, Mercu Mahadi ${ }^{2 *}$, Ni Kadek Karuni ${ }^{3^{*}}$ \\ Program Studi Kriya Fakultas Seni Rupa dan Desain \\ Institut Seni Indonesia Denpasar \\ Jl. Nusa Indah, Sumerta, Kota Denpasar, Kode Pos 80235 \\ Bali. Indonesia \\ Email:wayanmudra@isi-dps.ac.id,mercumahadi@gmail.com,dan \\ kadekkaruni@ymail.com
}

\begin{abstract}
Abstrak
Bali merupakan daerah destinasi wisata dunia yang dikunjungi wisatawan asing dari berbagai negara. Bali sebagai tujuan wisata menyediakan produk-produk kriya inovatif untuk disuguhkan kepada wisatawan asing dan wisatawan nusantara. Tujuan penelitian ini adalah untuk mendiskripsikan produk-produk kriya inovatif yang telah dihasilkan perajin Bali dalam memenuhi kebutuhan pariwisata. Penelitian ini merupakan penelitian sampel menggunakan pendekatan proposive sampling dan teknik pengumpulan data dilakukan dengan observasi, wawancara, dan dokumentasi. Dokumentasi juga dilakukan melalui media on line. Lokasi pengambilan sampel dilakukan tahun 2020 di beberapa tempat di Bali sesuai keberadaan subjek penelitian. Hasil penelitian menunjukkan produkproduk kriya inovatif yang dihasilkan perajin di Bali pada era global ini adalah produk-produk yang terbuat dari kayu, bambu dalam bentuk anyaman, logam, kain, dan keramik. Perajin melakukan inovasi produk dalam bidang bentuk, bahan, ornamen dan finishing. Inovasi yang dikembangkan perajin masih berakar pada budaya dan tradisi Bali, sehingga produk-produk kriya inovatif yang dihasilkan kental dengan identitas budaya lokal yaitu Bali. Peneliti berharap inovasi terus bisa dilakukan oleh perajin tanpa merusak akar budaya Bali, sehingga pelestarian budaya Bali tetap ajeg sepanjang masa.
\end{abstract}

Kata Kunci: inovasi, kriya, perajin, bali, global.

\begin{abstract}
Bali was a world tourist destination visited by foreign tourists from various countries. Bali as a tourist destination provides innovative craft products to be presented to foreign tourists and domestic tourists. The purpose of this research to describe the innovative craft products that have been produced by Bali craftsman in meeting tourism needs. This research was a sample study using a proposive sampling approach and data collection techniques carried out by observation, interviews, and documentation. Documentation also done through online media. Sampling locations were carried out in 2020 in several places in Bali according to the research subjects. The results showed that the innovative craft products produced by craftsman in Bali in this global era were products made from wood, bamboo in the form of woven, metal, fabric, and ceramics. Crafmans innovate products in the fields of form, materials, ornamentation and finishing. The innovations developed by craftsman ware still rooted in Balinese culture and traditions, so that innovative craft products produced are thick with local cultural identity, namely Bali. Researchers hope that innovation can continue to be carried out by craftmans without damaging the cultural of Bali, so that the preservation of Balinese culture remains unchanged for all time.
\end{abstract}

Keywords: innovation, craft, crafter, bali, global..

\section{PENDAHULUAN}

Bali sebagai daerah tujuan wisata dunia memiliki keunikan tersendiri yang berbeda dengan daerah lainnya di Indonesia bahkan di dunia, sehingga menjadi tujuan wisata favorit waisatawan manca negara untuk berwisata ke Bali. Bali yang unik dan khas ini pernah diwacanakan sebagai museum hidup oleh pemerintah Belanda karena merupakan penerus warisan budaya Hindhu Majapahit yang perlu terus dikonservasi dari pengaruh modernisasi Barat (Sendra,
2016: 104). Bali yang dicitrakan sebagai museum hidup dipandang menjadi nilai jual yang sangat berharga bagi pariwisata Bali (Suryawan, 2010: 38). Bali telah meraih berbagai penghargaan dalam bidang pariwisata. Penghargaan yang diterima Bali dua tahun terakhir ini, misalnya sebagai the best destination of the year dari TTG (Travel Trade Gazette) Award 2019 (KBRI Bangkok dan Kementerian Pariwisata RI, 2019), dansebagai 3 katagori award sekaligus yakni sebagai Top 10 Overseas Destination, Top 10 Luxury 
Travel Destination dan Top 10 Honeymoon Destination for Chinnese Tourists selama tahun 2017 dalam Global Destination Marketing Summit and World Culture and Tourism Forum diselenggarakan oleh Pemerintah Tiongkok dan C-Trip di Xanxi Convention Center, Xian Propinsi Xanxi Tiongkok 19 April 2018 (Saputra, 2018).

Bentuk-bentuk pengakuan dunia di atas menunjukkan pariwisata Bali adalah tujuan wisata yang manarik dan didukung oleh fasilitas pariwisata yang baik serta tersedianya produk-produk kriya berkualitas sebagai souvenir. Produk-produk kriya penunjang pariwisata Bali adalah hasil inovasi perajin yang masih kuat mempertahankan budaya tradisi dan pariwisata merupakan arena pasar kriya tersebut sehingga keduanya saling berkaitan yang tidak bisa dilepaskan satu dengan yang lainnya. Hal ini juga dinyatakan Sukarini dan kawan-kawan (2019:49) bahwa perkembangan industri seni kriya di Bali tidak bisa dilepaskan dari kemajuan pariwisata yang begitu pesat. Secara epistimologi pernyataan ini menunjukkan dua hal yang berbeda namun keberadaannya saling membutuhkan. Bali memiliki banyak seniman termasuk di dalamnya seniman kriya yang ahli dibidangnya masing-masing yang mampu menghasilkan produk-produk kriya berkualitas tinggi. Seniman-seniman tersebut tumbuh secara otodidak di desa-desa di Bali dalam bentuk usaha kecil atau usaha rumahan (home industry). Terkait dengan kesenimanan orang Bali ini, seorang seniman Meksiko bernama Miguel Covarrubias (dalam Adrian Vickers, 2012: 293) menulis bahwa setiap orang Bali layak disebut seniman.

Masyarakat Bali yang mayoritas beragama Hindu dikenal sangat kuat dalam mempertahankan budaya, adat dan tradisinya. Masyarakat Bali dikenal sangat fleksibel menerima pengaruh budaya dari luar dan diterima secara selektif disesuaikan dengan kondisi yang ada tanpa menghilangkan akar budaya setempat. Hal ini tercermin dalam berbagai kehidupan masyarakat Bali sehari-hari, termasuk dalam mengembangkan produk-produk kriya yang dilakukan oleh perajin dan pencinta produk kriya lainnya. Perajin dalam mengembangkan produk kriya selalu berakar pada budaya dan tradisi Bali.Bagi perajin budaya tradisi Bali menjadi modal berkarya yang tidak habis-habisnya untuk digali dan dikembangkan dalam berbagai produk kriya. Bali sangat kaya dengan budaya tradisi yang berkembang dipedesaan maupun diperkotaan dan pada era global ini masih tetap dapat dijumpai dan tumbuh semakin kuat. Sebelumnya banyak yang mengkhawatirkan perubahan zaman akan
Gorga Jurnal Seni Rupa

Volume 09 Nomor 01 Januari-Juni 2020

p-ISSN: 2301-5942 | e-ISSN: 2580-2380

menggilas budaya tradisi dan muncul budaya-budaya baru yang lepas dari tradisi selama ini. Namun faktanya pernyataan tersebut belum terlihat sampai saat ini, budaya dan tradisi Bali terlihat makin tumbuh dan berkembang di tengah-tengah masyarakat pendukungnya pada era global saat ini yang telah memasuki era disrupsi 4.0.

Bali saat ini memang menjadi sasaran pasar kriya dari berbagai daerah di Indonesia, misalnya produk kriya dari Jawa, Lombok, dan daerah-daerah lainnya. Hal ini menjadi pertanda bahwa Bali menjadi arena pasar bagi para pedagang produk kriya untuk uji coba pasar dan juga sebagai tempat pemasaran internasional. Sebagai contoh pada penelitian Mudra (2016) dijelaskan Bali telah menjadi pusat pemasaran berbagai jenis produk gerabah dari berbagai daerah di Indonesia misalnya dari Yogyakarta, Lombok, Jepara, dan Serang Banten. Penelitian Sunarini (2016) menjelaskan produk gerabah Serang Banten Jawa Barat kini sudah diproduksi di Bali (Mudra, dkk, 2019: 1).

Peran dan perkembangan produk kriya inovatif di Bali dari masa-kemasa belum banyak ditulis secara khusus oleh para penulis maupun para peneliti. Penelitian yang menyangkut produk kriya di Bali telah banyak ditemukan, tetapi belum banyak yang membahas secara mendalam dari sisi kreatifitas dan inovasi dari produk kriya tersebut. Produk kriya banyak ditulis dikaitkan dengan objek tulisan lainnya, sehingga peran kriya terlihat hanya sebagai penjelasan tambahan dari objek tulisan tertentu. Maka dari itu tulisan ini menjadi sangat penting untuk dipublikasikan.Tujuan dari penulisan artikel ini adalah untuk mendiskripsikan produk-produk kriya inovatif yang dihasilkan perajin Bali dalam memenuhi kebutuhan pariwisata. Inovasi produk-produk kriya tersebut dideskripsikan dari keragaman bahan misalnya terbuat dari kain, bambu, rotan, keramik, kayu, logam/besi, dan lain-lain. Sedangkan inovasi dijelaskan dari variabel bentuk, ornamen dan fungsi.

\section{KAJIAN TEORI}

Inovasi dapat di artikan sebagai sesuatu yang baru, penyempurnaan dari sebelumnya, wujudnya bisa dalam bentuk benda atau gagasan. Seorang yang melakukan inovasi disebut inovator mengahasilkan karya yang bersifat inovatif atau karya yang bersifat baru. Sebagai contoh inovasi produk kriya kebaruannya dapat dilihat dari segi bentuk, fungsi, finishing atau baru dari segi ornamennya. Tingkat capaian inovasi dari masing-masing produk berbedabeda dan dapat diukur secara kuantitatif maupun kualitatif, walaupun terkadang sulit dilakukan. Inovasi 
Gorga Jurnal Seni Rupa

Volume 09 Nomor 01 Januari-Juni 2020

p-ISSN: 2301-5942 | e-ISSN: 2580-2380

dilakukan sesuai kebutuhan untuk meningkatkan efektifitas kehidupan manusia yang biasanya dikerjakan melalui kegiatan penelitian formal maupun tidak formal. Undang-Undang Republik Indonesia Nomor 18 Tahun 2002 menyebutkan "Inovasi adalah kegiatan penelitian, pengembangan, dan/atau perekayasaan yang bertujuan mengembangkan penerapan praktis nilai dan konteks ilmu pengetahuan yang baru, atau cara baru untuk menerapkan ilmu pengetahuan dan teknologi yang telah ada ke dalam produk atau proses produksi”

Inovasi pertama kali diperkenalkan oleh Schumpeter tahun 1934. Schumpeter menjelaskan inovasi adalah mengkreasikan dan mengimplementasikan sesuatu menjadi kombinasi baru. Inovasi ini dapat menambah nilai produk, pelayanan, proses kerja, pemasaran, system pengiriman, dan kebijakan, tidak hanya bagi perusahaan tetapi juga pemegang saham dan masyarakat (de Jong \& Den Hartog, 2003 dalam Helmi: 2009: 1). Penekanan Schumpeter pada inovasi di atas terletak pada kreasi, implementasi, dan kombinasi yang baru untuk menambah nilai suatu produk.

Pemahaman produk kriya pada tulisan ini adalah produk-produk atau karya-karya yang dihasilkan oleh kriyawan atau perajin. Maka dari itu produk kriya sering diidentikkan dengan produk kerajinan yang memiliki fungsi praktis maupun fungsi hias. Kata kriya dalam pemakaian sehari-hari oleh masyarakat umum sering ditambahkan dengan kata seni sehingga menjadi kriya seni. Hal ini terjadi karena karya kriya tersebut lebih dipahami sebagai karya yang menonjolkan nilai seninya dibandingkan nialai fungsunya. Seni kriya adalah cabang seni rupa yang sangat memerlukan kekriyaan (craftmanship) yang tinggi seperti misalnya ukir kayu, seni keramik, anyam-anyaman, dsb. (Soedarso Sp., 1990 :15).

Sedangkan SP. Gustami (1992:71) menjelaskan bahwa seni kriya adalah suatu karya seni yang unik dan karakteristik, di dalamnya mengandung nilai-nilai estetik, simbolik, filosofis, dan fungsi. Perwujudannya seni kriya di dukung "craftsmanship" tinggi, sehingga kehadirannya dikelompokkan kedalan seni adiluhung. Senada dengan Gustami, Soedarso (1990:15) menyebutkan seni kriya sangat memerlukan kekriyaan (craftmanship) yang tinggi seperti ukir kayu, seni keramik, anyam-anyaman, dan sebagainya.

\section{METODE PENELITIAN}

Populasi penelitian ini adalah semua produk kriya Bali yang inovatif yang terdiri dari berbagai bahan, namun penelitian ini dilakukan dengan penelitian sampel dengan sajian data kualitatif. Karena sumber data tidak terhitung jumlahnya, sehingga tidak memungkinkan semua diambil sebagai sampel. Sumber data ditentukan dengan proposive sampling, yaitu teknik pengambilan sampel penelitian ditentukan berdasarkan kriteria-kriteria tertentu (Sugiyono, 2008). Kreteria sampel yang dimaksud dalam penelitian ini adalah produk kriya Bali yang inovatif, ditentukan berdasarkan bahan yang digunakan seperti terbuat dari anyaman bambu atau rotan, kayu, logam, dan keramik. Inovatif didasarkan pada kreteria kreatif dan dapat menambah nilai produk yang diinovasi, misalnya nilai penjualan, nilai budaya dan nilai lainnya sesuai tujuan perwujudan kriya tersebut. Pengumpulan data dilakukan dengan observasi, wawancara, dan dokumentasi. Dokumentasi dilakukan melalui penelusuran buku, hasil penelitian, dan jurnal yang diperoleh melalui media on line. Lokasi pengambilan sampel dilakukan di beberapa tempat di Bali tahun 2020.

\section{HASIL DAN PEMBAHASAN \\ 1.Hasil}

Produk kriya hasil inovasi di Bali ditemukan dalam berbagai bahan, motif, finishing, maupun fungsi. Pada tulisan ini subjek penelitian dijelaskan berdasarkan bahan yang dipakai dari produk kriya tersebut. Produk kriya inovatif di Bali yang terbuat dari bahan anyaman seperti bambu diantaranya ditemukan dalam bentuk benda yang disebut sokasi. Sokasi adalah sejenis bakul tertutup khas Bali yang dibuat mempergunakan jenisjenis bambu buluh (Arinasa, 2004:17). Perkembangan sokasi saat ini (2020) selain menggunakan bambu, sokasi juga dibuat menggunakan bahan gulungan kertas koran bekas, serta bahan-bahan sintetis seperti fiber dibuat menggunakan teknik cetak. Di Bali sokasi digunakan sebagai wadah, misalnya sebagai tempat nasi, sebagai tempat sesajen untuk persembahyangan di pura, di mrajan atau di tempat suci lainnya. Perajin sokasi di Bali terdapat dalam bentuk industri rumahan (home industry) dikerjakan oleh anggota keluarga dalam suatu kelompok. Karena fungsi-fungsi di atas, sokasi senantiasa dibuat indah dan menarik. Maka dari itu pembuatan sokasi tidak lepas dari sentuhan seni tangan-tangan terampil perajin. Kelompok perajin ini umumnya tersebar dipedesaan dibeberapa kabupaten di Bali seperti Bangli, Klungkung, Gianyar, Buleleng, dan Karangasem. Sokasi di Bali dikenal juga dengan nama keben dan beberapa contoh terlihat seperti gambar 1, 2 dan 3 di halaman berikutnya.

Produk kriya lainnya yang menadapatkan inovasi beberapa tahun terakhir ini adalah produk kipas yang 


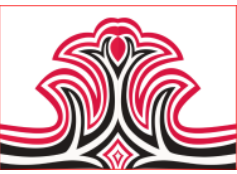

terbuat dari bahan kayu dan kain. Kipas ini banyak dipergunakan sebagai asesoris pemanis dalam pembuatan foto pra nikah (prewedding) yaitu proses pemotretan yang dilakukan pasangan penganten sebelum hari pernikahan. Produk kipas jenis ini banyak diproduksi oleh perajin di Kabupaten Klungkung misalnya usaha Kirtania Wayang Kamasan yang menginovasi berbagai jenis kipas tangan dan mendapat tanggapan positif dari masyarakat. Beberapa artikel menyebutkan penggunaan benda-benda asesoris pemanis dalam pembuatan foto prewedding bertujuan untuk manmpilkan objek foto berkesan mewah, glamor, romantis, dan ceria sesuai konsep yang diusung.Jenis-jenis kipas ini dilihat dari ornamennya, dapat dibedakan menjadi kipas wayang, kipas ornamen bunga, dan kipas polos warna warni tanpa ornamen. Selain itu ada juga kipas untuk souvenir seperti kipas prada, kipas batik, dan kipas penari. Produk souvenir ini dipasarkan langsung kepada wisatawan melalui pasar-pasar seni dan juga melalui media online. Beberapa jenis kipas ini bisa dilihat pada contoh gambar 4, 5 dan 6 di halaman berikutnya.

Produk inovatif yang terbuat dari bahan kayu juga ditemukan dalam bentuk gitar seperti terlihat pada gambar 7 halaman berikut. Pekerjaan membuat gitar ini merupakan keahlian khusus yang dimiliki perorangan, sedikit berbeda dengan pembuatan produk kriya lainnya. Pembuat gitar yang cukup dikenal di Bali adalah I Wayan Tuges dari Desa Guwang Sukawati Gianyar dengan merek gitarnya "Blueberry", dan I Putu Sunarta dari Desa Dukuh Desa Penebel Tabanan dengan merek gitarnya "Divart".

Produk kriya Bali inovatif lainnya ditemukan dari bahan logam. Perusahaan yang bergerak khusus terkait dengan pengolahan logam ini yaitu "UD. Kamasan Bali" di Desa Kamasan Kabupaten Klungkung Bali dan "UD. Mulya" di Desa Kapal Kecamatan Mengwi Badung. UD. Kamasan Bali produk utama yang dihasilkan adalah uang kepeng (di Bali disebut pis bolong) yang banyak diperlukan oleh masyarakat Hindu di Bali untuk perlengkapan upacara agama. Produk uang kepeng ini juga merupakan bahan yang dipakai untuk menghasilkan produk-produk kriya baru seperti: salang, patung, orgonite, genta, liontin (gambar 8), dan lain-lain. Uang kepeng terbuat dari 5 macam logam yang disebut panca datu yaitu: emas, perak, perunggu, tembaga dan besi (kamasanbali.business.site, diakses 2020). Produk kriya logam UD. Kamasan Bali juga diekspor keluar negeri dalam bentuk hiasan dinding, dan patung.
Gorga Jurnal Seni Rupa

Volume 09 Nomor 01 Januari-Juni 2020 p-ISSN: 2301-5942 | e-ISSN: 2580-2380

Produk kerajinan logam lainnya banyak juga ditemukan di Desa Kamasan Klungkung yang mengolah selongsong pluru menjadi berbagai bentuk kerajinan. Namun saat ini jenis kerajinan ini sudah mulai sepi dari pesanan sehingga kegiatan perajin menurun dan banyak pihak memperkirakan kerajinan ini akan punah. Selain itu ada juga inovasi berupa tempat lampu gantung dari bahan aluminium seperti terlihat pada gambar 9. Produk ini sudah mulai terlihat sejak acara Pesta Kesenian Bali 2014, bentuk dan ukirannya simpel dan cukup menarik.

Inovasi produk kriya di Bali juga terlihat pada produkproduk keramik. Produk keramik inovatif ini dikerjakan oleh perusahaan-perusahaan keramik dan lembaga pendidikan yang memiliki program studi kriya dengan konsentrasi minat kriya keramik seperti Prodi Kriya FSRD Institut Seni Indonesia Denpasar dan beberapa SMK yang memiliki pembelajaran kriya keramik. Karya-karya yang dihasilkan dari lembaga pendidikan ini banyak terinspirasi dari alam yang diolah sesuai kreatifitas mahasiswa namun masih tetap mengacu pada nilai-nilai fungsi yang dibebankan pada karya-karya tersebut. Sebagai contoh karya kriya keramik inovatif mahasiswa PS Kriya FSRD ISI Denpasar hasil tugas akhir tahun 2017 seperti karyakarya I Gede Rai Wahyudi dengan tema "Keramik Pancuran", I Made Ariana dengan tema "Lampu Hias", I Nyoman Juliana dengan tema "Motif Daun dan Buah Kelapa pada Keramik", I Gede Wana Arsa Putra dengan tema "Keramik Kapal Layar Nusantara", dan Abdul Azis dengan tema "Tempat Speaker Keramik". Contoh beberapa karya dari pencipta keramik ini seperti terlihat pada gambar gambar 10 dan 11. Karya Wahyudi dan Ariana tersebut dapat mewakili karya-karya keramik inovatif yang dihasilkan mahasiswa FSRD ISI Denpasar, karena menampilkan nilai kreatifitas cukup tinggi.

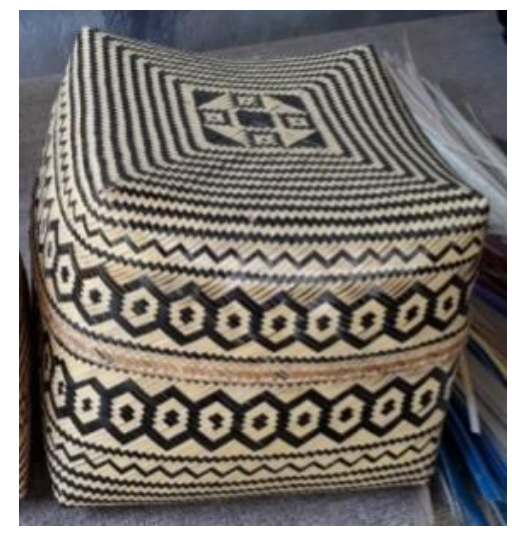

Gambar 1. Sokasi Berornamen Geometris (Sumber: I Wayan Mudra, 2019) 

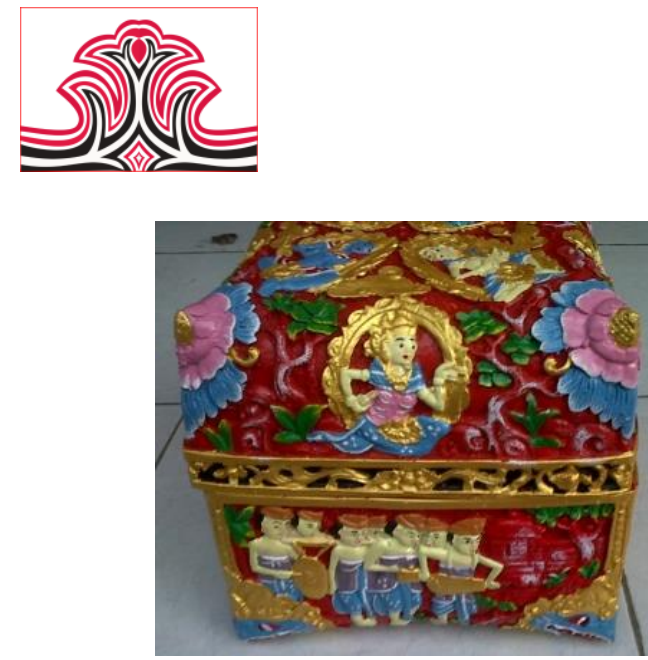

Gambar 2. Sokasi Bahan Fiber dan Berornamen Wayang (Sumber: Agungpibber, 2020)

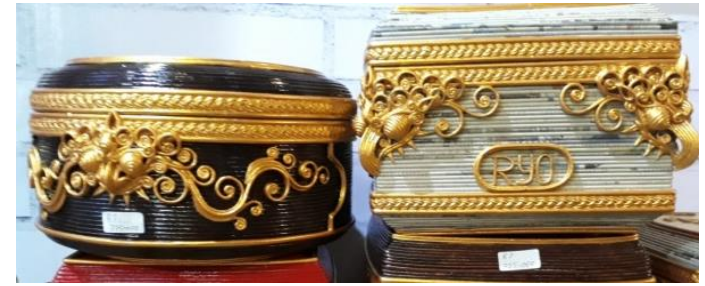

Gambar 3. Sokasi dari Bahan Koran Berornamen Motif Garis Lengkung (Sumber: Kirtania, 2020)

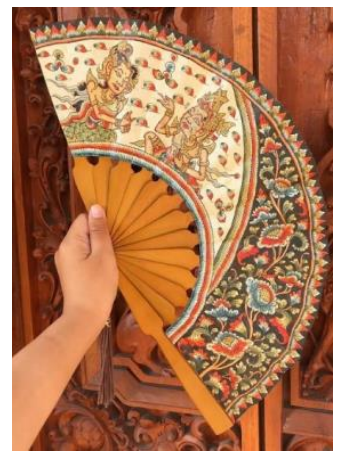

Gambar 4. Kipas Prewedding (Sumber: Kirtania, 2020)

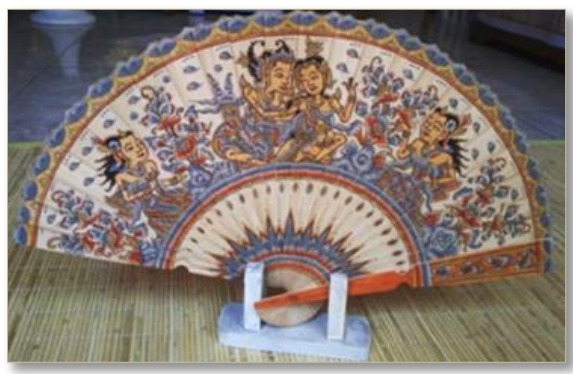

Gambar 5. Kipas Wayang

(Sumber: Kirtania, 2020)
Gorga Jurnal Seni Rupa

Volume 09 Nomor 01 Januari-Juni 2020 p-ISSN: 2301-5942 | e-ISSN: 2580-2380

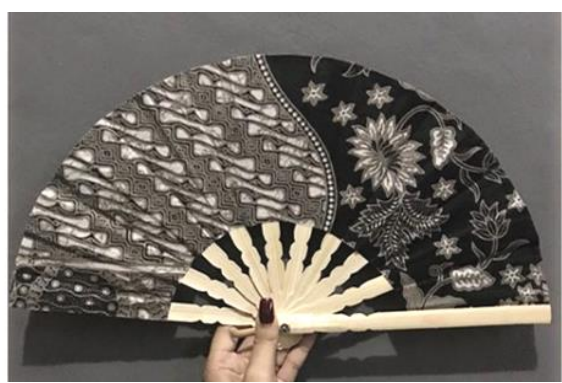

Gambar 6. Kipas Batik

(Sumber: Kipas Batik Bali, 2020)
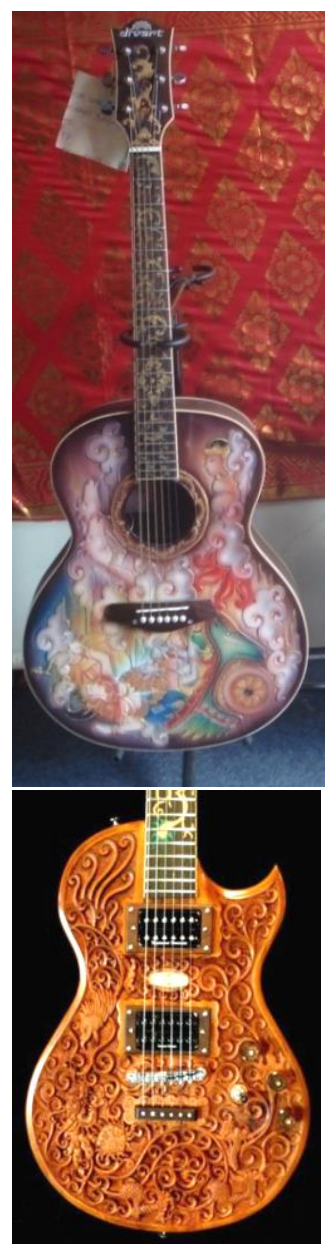

Gambar 7. Gitar Ornamen Wayang dan Gitar Ukir Tribal Naga Garuda

(Sumber: I Wayan Mudra, 2014 dan Yoga, 2015)

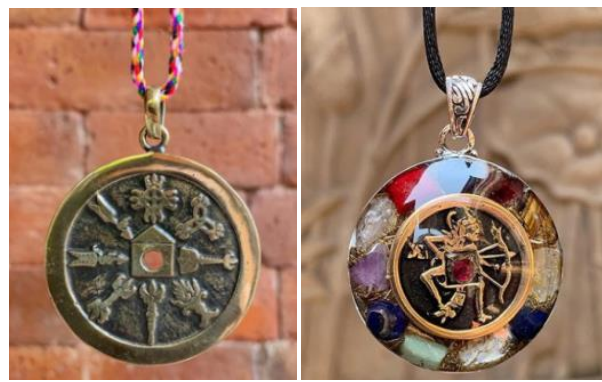

Gambar 8. Liontin Nawa Sanga dan Arjuna Memanah (Sumber: Instagram.com/p/ByaU-WZAFre/) 

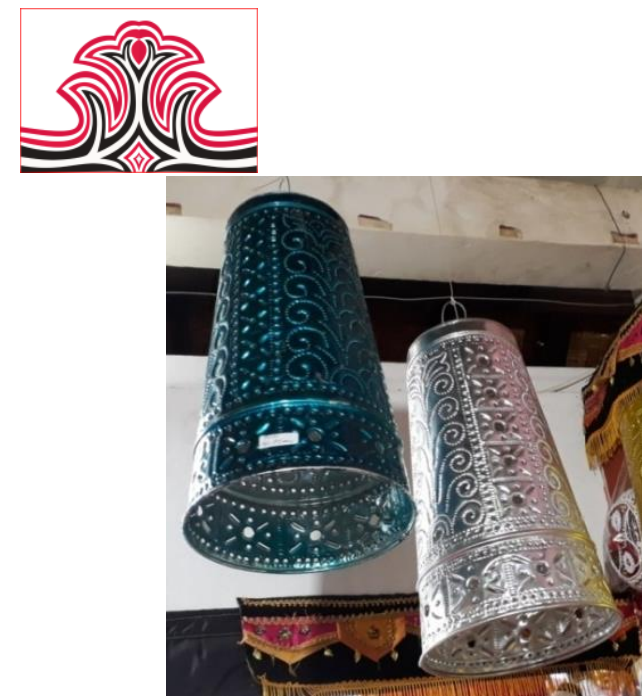

Gambar 9. Tempat Lampu Gantung (Sumber: I Wayan Mudra, 2014)

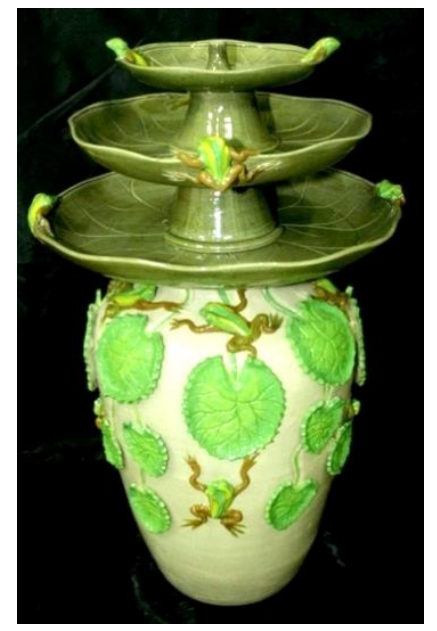

Gambar 10. Keramik Pancuran 4 (Sumber: Gede Rai Wahyudi Putra, 2017)

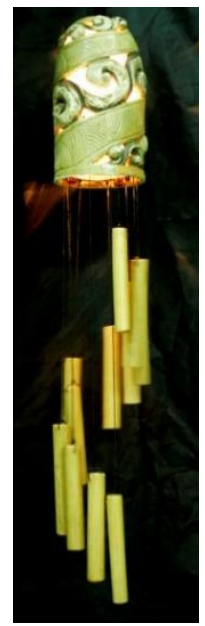

Gambar 11. Lampu Gantung (Sumber: Ariana, 2017)

\section{Pembahasan}

Pada produk sokasi sebagai contoh dalam tulisan ini yang dapat dikatakan sebagai sesuatu yang baru adalah dilihat dari perkembangan ornamen dan bahan yang dipakai. Produk gambar 1 dibuat dengan kualitas baik menggunakan bambu menerapkan ornamen
Gorga Jurnal Seni Rupa

Volume 09 Nomor 01 Januari-Juni 2020

p-ISSN: 2301-5942 | e-ISSN: 2580-2380

geometris merupakan produk yang keberadaannya sudah lama dan sampai sekarang (2020) masih terlihat dipasaran. Hal ini menunjukkan minat konsumen terhadap produk ini masih cukup baik. Sedangkan produk gambar 2 adalah sokasi yang relative baru terbuat dari bahan fiber dibuat dengan teknik cetak dan menerapkan ornamen wayang khas Bali. Dengan demikian inovasi dari produk ini dapat dilihat dari 3 hal yaitu dari segi bahan, ornamen, dan teknik pembuatan. Sedangkan produk ketiga yaitu gambar 4, inovasinya dapat dilihat dari bahan yang digunakan yaitu gulungan kertas koran, bentuk dan tampilan ornamen. Inovasi penggunaan kertas koran bekas sebagai bahan pembuatan produk kerajinan ini di Bali beberapa tahun terakhir ini menjadi trend dan cukup diminati oleh konsumen lokal. Bentuk ornamen yang terdiri dari rangkaian garis lengkung yang menghasilkan kesan lembut merupakan garis lengkung dibuat menggunakan gulungan kertas koran bekas. Ornamen khas Bali tidak bisa dimunculkan dengan penggunaan bahan ini.Inovasi juga terlihat dari penggunaan cat warna yang bermacam-macam serta difinishing dengan warna keemasan (prada) sehingga tampilannya menjadi cerah dan meriah.

Inovasi pada produk kipas seperti pada gambar 4, 5 dan 6 dapat dijelaskan dari bahan yang digunakan dan ornamen bahkan fungsinya.Ornamen wayang dan bunga pada gambar 4 dan 5 merupakan hasil inovasi perajin dari produk-produk kipas sebelumnya. Ornamen jenis ini merupakan ornamen baru pada kipas seiring tuntutan pasar yang semakin berkembang. Sebelumnya wayang belum pernah diterapkan secara detail pada kipas seperti pada kipas ini. Penerapan ornamen ini membuat produk kipas ini terlihat elegan dan mampu menampilkan kualitas berkelas tinggi. Sedangkan produk kipas batik gambar 6 , inovatif hanya terlihat dari bahan yang digunakan yaitu batik. Batik bukan merupakan hasilperajin lokal Bali, namun perajin mencoba mengkreasikan bahan tersebut dalam produk kipas. Kipas jenis bisa didapatkan dipasar-pasar seni dengan harga yang relative lebih murah dibandingkan dengan kedua jenis kipas di atas.

Inovasi pada produk kriya berupa gitar seperti pada gambar 7 di atas yang paling menonjol dapat dilihat dari ornamennya. Ornamen gitar pertama menerapkan motif wayang khas Bali dibuat dengan teknik ukir dan lukis. Motif wayang dikreasikan berbeda dengan wayang khas Bali pada umumnya yang menjadi rujukan disertai garis-garis lengkung menyerupai awan. Demikian juga pewarnaan menggunakan warna-warna yang terkesan lembut menambah daya 


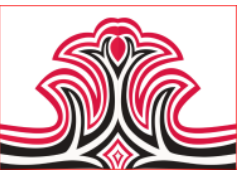

tarik karya gitar ini.Gitar kedua diberi nama Gitar Ukir Tribal Naga Garuda menerapkan ornamen motif kepala naga dan kepala burung garuda. Ornamen gitar ini dibuat dengan teknik ukir dengan detail yang cukup tinggi, kepala burung garuda dan kepala naga digambarkan berhadapan tanpa kepala. Penggambaran motif ukiran didominasi oleh garis-garis lengkung yang menyerupai pepatran yang ada di Bali, namun tidak jelas mengadopsi motif tertentu. Pewarnaan ornamen dengan satu warna coklat muda, sehingga gitar ini terlihat simpel dan elegan. Tampilan ornamen menjadi kekuatan inovasi karya ini.

Produk kriya inovatif lainnya yang termasuk berbahan logam adalah lointin (gambar 8).Karya ini merupakan pembaharuan dari produk uang kepeng (di Bali dikenal dengan pis bolong) buatan China. Kemudian karena kelangkaan uang kepeng China ini dan kebutuhan masyarakat sebagai perlengkapan upacara keagamaan, maka muncullah usaha yang memproduksi uang kepeng ini di Bali seperti telah disebutkan di atas. Inovasi dari produk ini dapat dilihat dari fungsi, bahan dan ornamen. Inovasi dari fungsi dulunya karya yang menjadi insprasi pembuatan karya ini yaitu uang kepeng berfungsi sebagai uang yangg diperlukan pada upacara keagamaan, namun saat ini digunakan sebagai souvenir yaitu liontin yang menarik. Bahan juga diperbaharui dengan penggunaan bahan-bahan yang mampu menimbulkan kesan mengkilap dan mewah. Ornamen juga demikian, dulunya uang kepeng tulisan cina dapat dianggap sebagai ornamen namun sekarang dibuat sesuai tradisi yang ada di Bali misalnya senjata nawa sanga dan ornamen wayang Arjuna memanah.

Selanjutnya tempat lampu gantung gambar 9 produk yang sederhana dapat dikatagorikan sebagai karya kriya logam yang inovatif. Inovasi perajin terlihat dari penggunaan bahan yaitu menggunakan bahan seng, sebelumnya tempat lampu gantung model ini sering menggunakan anyaman bambu atau rotan. Inovasi lampu gantung yang cukup menarik, vertikal, cukup ringan dan harga yang relative murah. Ornamennya tidak terlalu jelas menampilkan ornamen tradisi, dan ornamen ini sering diterapkan pada pembuatan sokasi, sangku, dan bokoran yang terbuat dari seng.

Karya terakhir yang disertakan pada tulisan ini adalah kriya keramik (gambar 10 dan 11). Kriya keramik gambar 11 dapat disebut sebagai karya inovatif dikaji dari bentuk yang ditampilkan. Karya ini penggabungan dari dua bentuk utama yaitu bentuk guci bagian bawah yang digabung dengan bentuk 3 bentuk piring motif daun tunjung bersusun di atasnya.
Gorga Jurnal Seni Rupa

Volume 09 Nomor 01 Januari-Juni 2020

p-ISSN: 2301-5942 | e-ISSN: 2580-2380

Ornamen badan guci juga menggunakan motif daun tunjung dan kodok, serta diglasir menggunakan glasir hijau. Sedangkan karya gambar 11 inovasinya terlihat dari penggabungan bambu dan keramik pada karya tempat lampu gantung.Inovasi kap lampu gantung dengan bahan keramik ini memang sangat riskan karena cukup berat dan menimbulkan kekhawatiran jika sewaktu-waktu bisa jatuh dan pecah.

\section{KESIMPULA DAN SARAN}

\section{Kesimpulan}

Inovasi produk kriya di Bali sampai saat ini (2020) dapat dilihat dari berbagai variavel, misalnya dari segi bentuk, fungsi, bahan, dan ornamen. Inovasi lebih dominan terjadi pada ornamen dibandingkan vaiabel lainnya, hal ini hampir terlihat pada setiap produk kriya. Inovasi pada ornamen perkembangannya terjadi sangat cepat dan paling mudah dilakukan oleh perajin dibandingkan mengembangkan yang lainnya. Maka dari itu setiap tahun Pesta Kesenian Bali dilakukan ada saja terlihat produk-produk kriya baru yang ditampilkan perajin terutama dilihat dari segi ornamen yang diterapkan.

\section{Saran}

Kami perlu sampaikan beberapa hal dalam tulisan ini sebagai saran adalah perajin apapun bidangnya tetaplah berinovasi karena inovasi merupakan salah satu kekuatan dalam mempertahankan keberlangsungan sebuah usaha produk kerajinan. Namun dalam berinovasi harus tetap mempertimbangkan kebutuhan calon pengguna (user), jika dilakukan berlebihan produk tersebut akan sekedar menjadi produk inovasi yang menyenangkan penciptanya saja.

\section{DAFTAR RUJUKAN}

Arinasa, Ida Bagus Ketut. (2005). Keanekaragaman dan Penggunaan Jenis-jenis Bambu di Desa Tigawasa. Jurnal B I O D I VER S I T A $S, 6(1), 17-21$.

Covarrubias, Miguel. (2012). Manusia Bali adalah Seniman, dalam Bali Tempo Doulou oleh Adrian Vickers. (Penerjemah: Tim Komunitas Bambu), Depok: Komunitas Bambu.

Gustami, SP. (1992). Filosofi Seni Kriya Tradisional Indonesia.SENI, Jurnal Pengetahuan dan Penciptaan Seni, II (01) Januari, BP. ISI Yogyakarta.

KBRI Bangkok dan Kementerian Pariwisata RI. (2019). BALI RAIH PENGHARGAAN BEST DESTINATION OF THE YEAR, dari 
https://kemlu.go.id/bangkok (diakses 18

Januari 2020).

Mudra, I Wayan, I Gede Mugi Raharya, I Wayan Sukarya. (2019). Keramik dengan Ornamen

Motif Khas Wayang Bali. Denpasar:

LP2MPP ISI Dnpasar.

Saputra, Endang. (2018). Bali Raih Tiga Penghargaan Pariwisata Dunia Bergengsi di China dari https://jpp.go.id/ekonomi/pariwisata (diakses 17 Januari 2020).

Sendra, I. (2016). Paradigma Kepariwisataan Bali Tahun 1930-An: Studi Genealogi Kepariwisataan Budaya. Jurnal Kajian Bali (Journal Of Bali Studies), 6(2), 97-124.

Retrieved from https://ojs.unud.ac.id/index.php/kajianb ali/article/view/24896.

Soedarso, SP. (1990). Tinjauan Seni Sebuah Pengantar Untuk Apresiasi Seni. Yogyakarta: Saku Dayar Sana.

Sugiyono. 2008. Metode Penelitian Bisnis. Alfabeta: Bandung.

Sukarini, N. W., Beratha, N. L. S., \& Rajeg, I. M. (2019). Industrialisasi Seni Kriya di Desa Mas, Gianyar. Mudra Jurnal Seni Budaya, 34(1), 45-52. https://doi.org/10.31091/mudra.v34i1.634

Suryawan, I Ngurah. (2010). Genealogi Kekerasan dan Pergolakan Subaltern: Bara di Bali Utara. Jakarta: Penerbit Prenada Media Group.

Helmi, Avin Fadilla. (2009). Bagaimana Menciptakan Inovasi Produk? Buletin Psikologi Fakultas Psikologi Universitas Gadjah Mada, 17(1), 110.

\section{UNDANG-UNDANG REPUBLIK INDONESIA} NOMOR 18 TAHUN 2002, https://ftp.unpad.ac.id.

Yoga, Wayan Balik Sedana, Edi Eskak. (2015). UKIRAN BALI DALAM KREASI GITAR ELEKTRIK Balinese Carving in Electric Guitar Creation. Jurnal Dinamika Kerajinan dan Batik, 32(2), 117-126. 